\title{
Traumatic diaphragmatic hernia
}

\author{
Sanjiv Bhatia · Robin Kaushik · Rajdeep Singh · Rajeev Sharma · Ashok Attri · Usha Dalal · \\ Ashwani Dalal $\cdot$ Rajesh Bansiwal
}

Received: 25 October 2006 / Accepted: 23 April 2008

\begin{abstract}
Background Abdominal trauma is frequently encountered, but traumatic injuries to the diaphragm are often missed.

Material and methods A retrospective review of all the case files of patients presenting with traumatic diaphragmatic injury was performed. These patients were analyzed for their presentation, injury, surgery performed and outcome
\end{abstract}

Results A total of 14 patients were thus identified (12 males and 2 females). The average age was 31.5 years. Road traffic accidents were the most common cause, accounting for the majority of cases (12 patients). 10 patients presented within 24 hours of injury; the other 4 presented late $\left(2^{1 / 2}\right.$ months to 20 years) with the signs and symptoms of acute intestinal obstruction. The left side of the diaphragm was injured more commonly. Herniation of multiple intra abdominal viscera was common, with the stomach being the organ most commonly implicated. There were 2 deaths.

S. Bhatia $\cdot$ R. Kaushik $\cdot$ R. Singh $\cdot$ R. Sharma $\cdot$

A. Attri · U. Dalal · A. Dalal · R. Bansiwal

Department of Surgery,

Government Medical College and Hospital, Sector 32

Chandigarh - 160 030, India

R. Kaushik $(\square)$

e-mail: robinkaushik@gmail.com
Conclusions Traumatic injury to the diaphragm must be kept in mind while dealing with patients who have sustained abdominal trauma. The diagnosis can easily be picked up on chest $\mathrm{x}$-ray. Treatment is surgical, with simple suturing of the diaphragm with non - absorbable suture giving good result

\section{Introduction}

Blunt abdominal trauma is frequently encountered by surgeons the world over. Commonly, the injuries seen are of the liver, spleen and intestine, but any intra abdominal organ can be injured. The management of such injuries can be conservative if the patient is hemodynamically stable and does not have evidence of bowel injury, or, the patient may require surgery to deal with life threatening intra abdominal organ injury.

Traumatic diaphragmatic herniation (TDH) after injury is an unusual presentation of abdominal trauma, and as such, is liable to be missed if not suspected and looked for. Such an injury occurs in up to $7 \%$ of major blunt trauma victims and in $10-15 \%$ of patients with penetrating trauma to the lower chest [1]. The detection of these injuries is often difficult because of non specific clinical signs, the presence of additional intra abdominal injuries and other injuries that may demand urgent treatment and distract attention, [2] and at times, due to a lack of awareness of this clinical entity. A delayed diagnosis of traumatic diaphragmatic injury leading to herniation of the intra abdominal contents through the ensuing defect is associated with an increased morbidity and mortality [1]. 


\section{Material and methods}

We retrospectively reviewed the hospital records of all trauma patients who reported to our emergency department (a tertiary care referral center) between April 2002 and May 2006. Out of these, those who were diagnosed as having diaphragmatic injury with hernia were included in the study.

The records of these patients were then analyzed with respect to the mode of injury, time elapsed between injury and presentation, preoperative clinical signs and diagnosis, site of diaphragmatic rupture, contents of the sac, associated injuries, surgery performed, morbidity, mortality, and hospital stay.

\section{Results}

Of the 14 patients diagnosed to have traumatic diaphragmatic hernia after abdominal trauma, 12 were men and 2 were women. The age of the patients ranged from 9 to 55 years (mean 31.5 years). Road traffic accidents were the most common cause, accounting for the majority of cases (12 patients). 10 patients presented within 24 hours of injury, and the remaining 4 presented late $\left(2^{1} / 2\right.$ months to 20 years) with the signs and symptoms of acute intestinal obstruction.

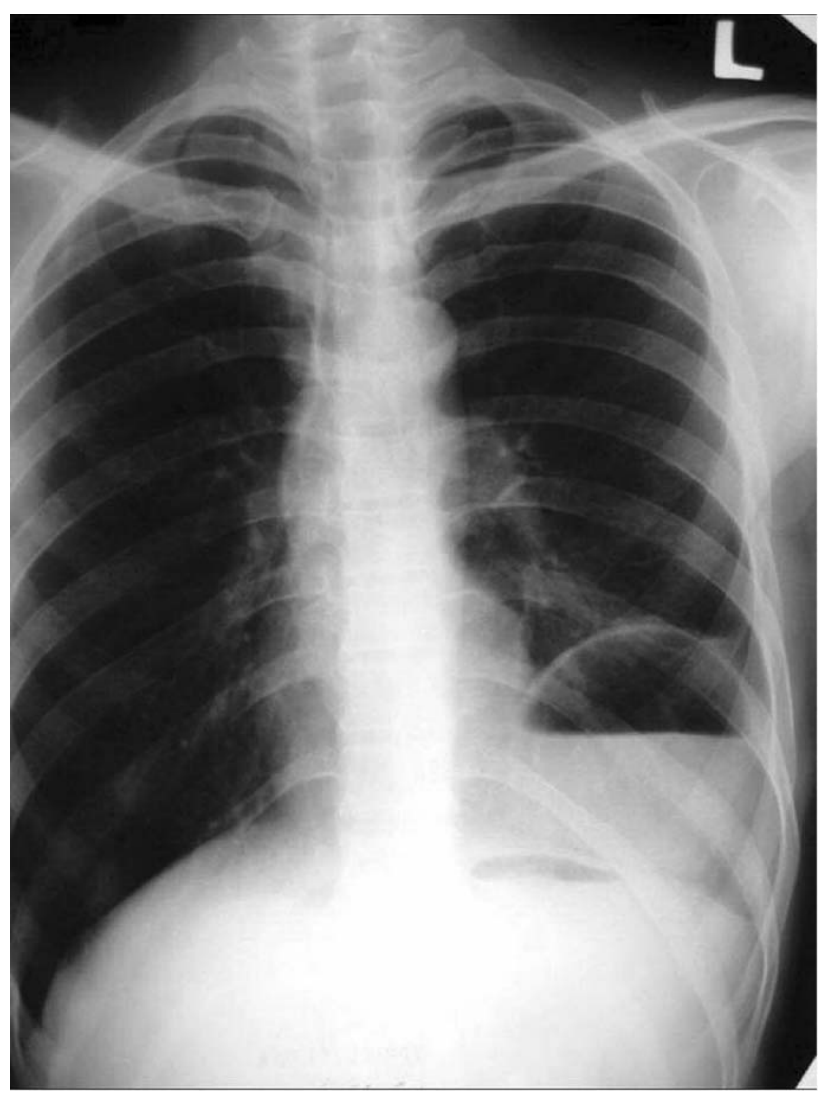

Fig. 1 Chest $\mathrm{x}$ ray in a patient with TDH with gastric bubble visible in the left chest
Clinically, the diagnosis was made in 7 of the 10 cases that presented to us immediately after sustaining trauma. As part of their trauma work-up, all patients had a plain chest $\mathrm{x}$-ray, which picked up the herniated gut loop in all seven patients; the features seen on chest $x$ ray that suggested the diagnosis were the presence of the gastric air bubble (Figs. 1-4), colon (Fig. 5) or both, stomach and colon (Fig. 6) in the chest. In the remaining cases, the diagnosis could only be made intra operatively, when the herniated intestinal contents were seen going into the chest through a diaphragmatic defect. Of the patients presenting late, the diagnosis was made pre operatively in 2 - one patient was referred to us with an upper GI contrast study that showed volvulus of the stomach, with the pyloroantrum lying in the left chest (Fig. 7); in another the stomach was seen in the chest cavity (Fig. 8). There were multiple associated injuries - rib fractures, splenic lacerations, and, lower extremity fractures were the commonest seen.

The left hemidiaphragm was the commonest site of rupture, seen in 12 patients; one patient had a right sided diaphragmatic injury, whereas another had a central diaphragmatic rupture. Herniation of multiple intra abdominal viscera was common, with the stomach being the most commonly implicated (in 13 patients). The next common organ to herniate was the greater omentum ( 9 patients), transverse colon (4 patients), spleen (3) liver (2) and small bowel (2).

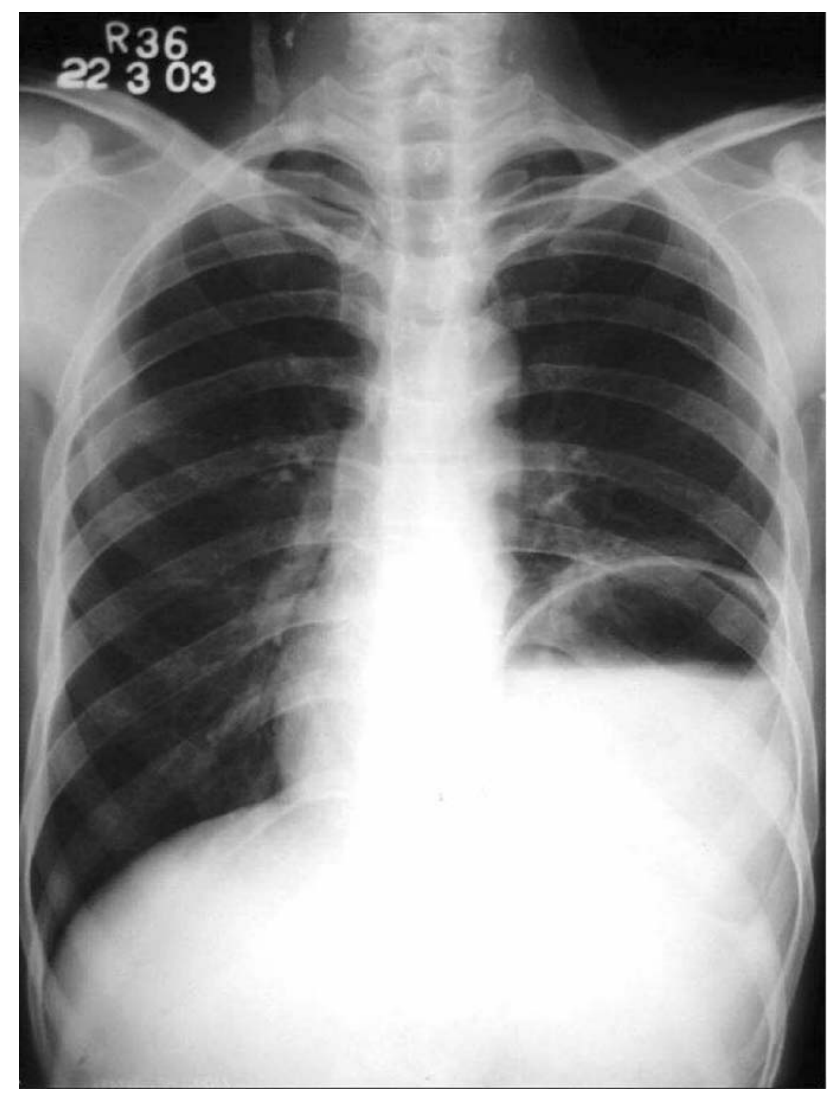

Fig. 2 Chest $x$ ray in a patient of TDH with gastric bubble in the left chest. The mediastinum is shifted to the right 


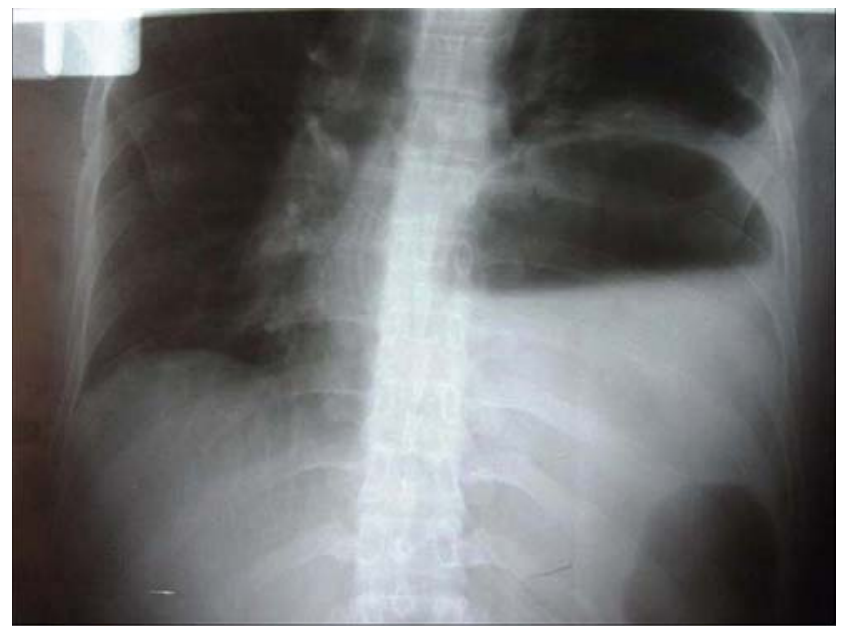

Fig. 3 Chest $x$ ray in a patient of TDH with gastric bubble visible in the left chest

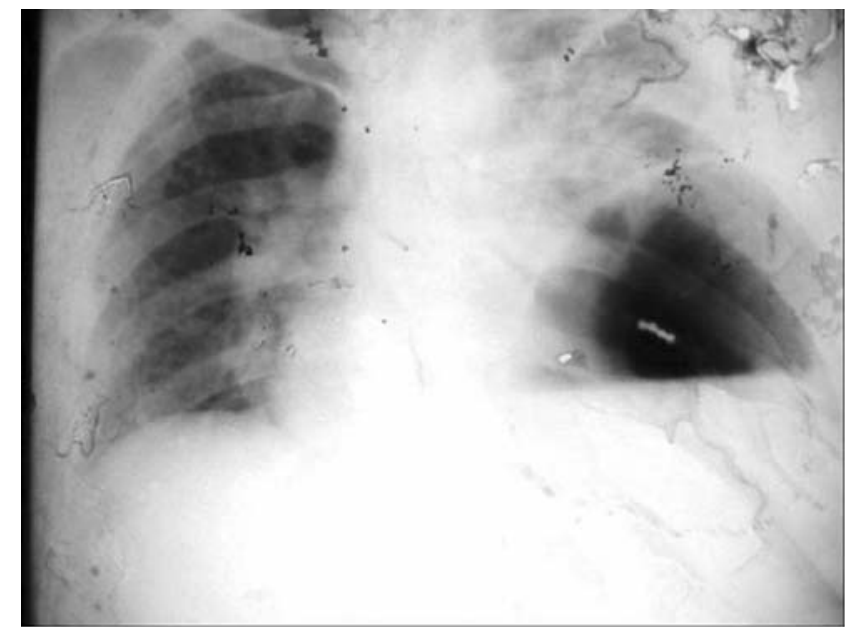

Fig. 4 Chest $x$ ray in a patient of TDH with gastric bubble visible in the left chest. Note the position of the Ryle's tube within the gastric air bubble

After reducing the contents, the diaphragm was repaired using large diameter ( 0 or 00$)$ interrupted polypropylene suture. In two cases (one with early and one with a delayed presentation), thoracotomy had to be performed to relieve the adhesions in the chest so that the contents could safely be reposited into the abdomen. The diaphragmatic defect could be closed primarily in all the patients. Surgical treatment of any associated injury, if needed, was performed simultaneously.

Two patients died - one patient with right sided herniation of the liver because of DIC secondary to massive blood transfusions, and the other, because of multiorgan failure. The hospital stay in the survivors varied from 5 to 39 days (average 17.8 days).

The details of the patients are tabulated in Table 1 (acutely presenting cases) and Table 2 (delayed presentation).

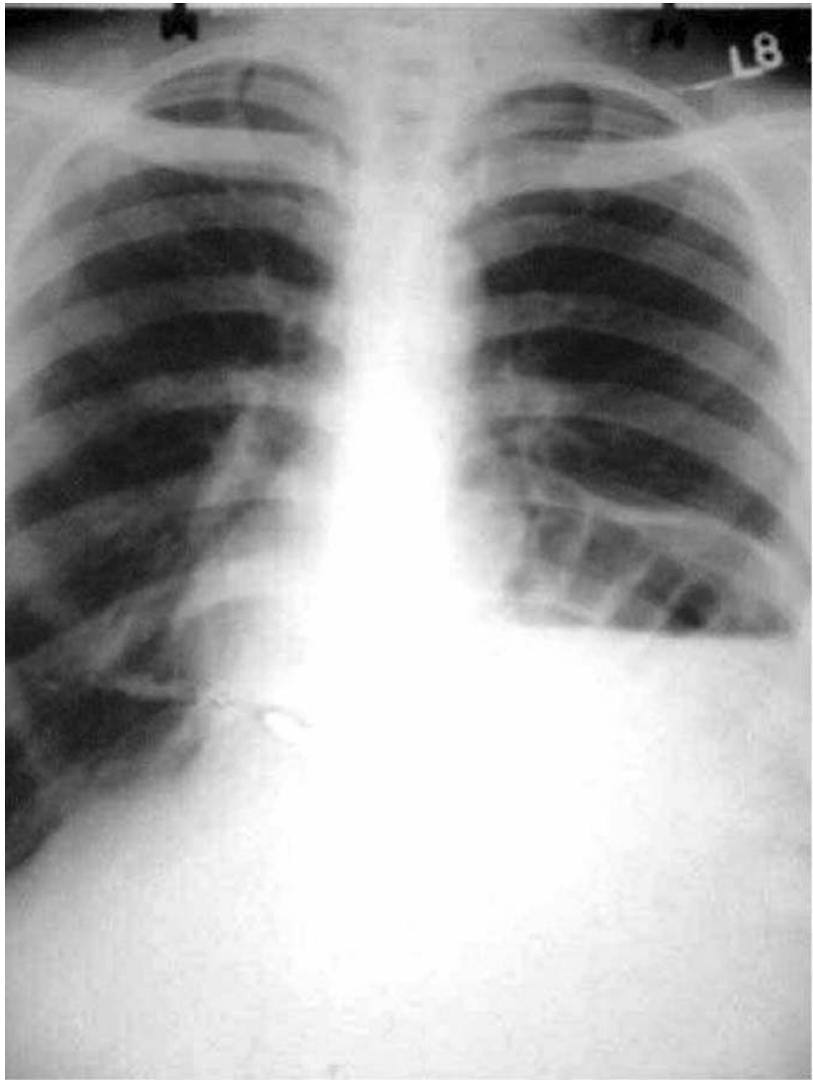

Fig. $5 \mathrm{TDH}$ with colon loop visible in the left chest and mediastinal shift to the right

\section{Discussion}

Despite having been first described in 1541 by Sennertus, [1] TDH still remains a diagnostic challenge in a majority of cases. The injury frequently remains unrecognized, being found on initial evaluation before surgical intervention in less than $50 \%$ of cases, or on laparotomy or on autopsy [1-3]. The increasing conservative management of patients with abdominal trauma has also contributed to TDH going unrecognized for years altogether, once it has been missed initially. The diagnosis may further be delayed in patients needing ventilation, as positive pressure ventilation may prevent initial herniation of the bowel loops through the diaphragmatic defect [4].

Although the majority of injuries occur secondary to blunt trauma, penetrating trauma to the upper abdomen and lower chest may also lead to diaphragmatic injury and herniation [5]. At the time of a blunt impact, there occurs, a sudden increase in the intra abdominal pressure that may rise to at least $1000 \mathrm{~cm}$ of water from a normal of $2-10 \mathrm{cms}$ of water [5]. As can be appreciated, this increase in pressure is transmitted across the diaphragm, with a resultant avulsion of the diaphragmatic attachments. This may further be aggravated by a direct penetration of the diaphragm by rib fragments [2]. The presence of a preexisting 
Table 1 Acute diaphragmatic herniation - patient data

\begin{tabular}{|c|c|c|c|c|c|c|c|}
\hline $\begin{array}{l}\text { S. } \\
\text { No }\end{array}$ & Age & $\begin{array}{l}\text { Side of } \\
\text { injury }\end{array}$ & Contents & Associated Injury & Surgery ${ }^{\mathrm{a}}$ & $\begin{array}{l}\text { Hospital Stay } \\
\text { (in days) }\end{array}$ & Outcome \\
\hline 1 & 18 & Right & Right lobe of liver & $\begin{array}{l}\text { Liver laceration Pancreatic } \\
\text { injury Central abdominal } \\
\text { hematoma \# of ribs }\end{array}$ & $\begin{array}{l}\text { Laparotomy } \\
\text { Hepatorrhaphy }\end{array}$ & 03 & $\begin{array}{l}\text { Died due to } \\
\text { DIC from } \\
\text { massive blood } \\
\text { transfusion }\end{array}$ \\
\hline 2 & 09 & Left & $\begin{array}{l}\text { Stomach } \\
\text { Transverse Colon } \\
\text { Omentum }\end{array}$ & $\begin{array}{l}\text { Splenic injury } \\
\text { Retroperitoneal hematoma } \\
\text { \# right femur }\end{array}$ & $\begin{array}{l}\text { Laparotomy } \\
\text { Splenorrhaphy } \\
\text { Plating for femur }\end{array}$ & 11 & $\begin{array}{l}\text { Discharged } \\
\text { Well }\end{array}$ \\
\hline 3 & 30 & Left & Stomach & $\begin{array}{l}\text { C2 fracture } \\
\text { \# pelvis }\end{array}$ & Laparotomy & 14 & $\begin{array}{l}\text { Discharged } \\
\text { Well }\end{array}$ \\
\hline 4 & 24 & Left & $\begin{array}{l}\text { Stomach } \\
\text { Omentum }\end{array}$ & $\begin{array}{l}\text { Sigmoid colon perforation } \\
\text { Urinary bladder tear } \\
\text { \# pelvis and \# right femur }\end{array}$ & $\begin{array}{l}\text { Laparotomy } \\
\text { Sigmoid } \\
\text { perforation \& } \\
\text { bladder repair }\end{array}$ & 09 & $\begin{array}{l}\text { Died due to } \\
\text { multiorgan } \\
\text { failure }\end{array}$ \\
\hline 5 & 40 & Left & $\begin{array}{l}\text { Stomach } \\
\text { Omentum } \\
\text { Spleen }\end{array}$ & $\begin{array}{l}\text { Splenic injury } \\
\text { Pancreatic tail injury }\end{array}$ & $\begin{array}{l}\text { Laparotomy } \\
\text { splenectomy }\end{array}$ & 21 & $\begin{array}{l}\text { Discharged } \\
\text { Well }\end{array}$ \\
\hline 6 & 14 & Left & $\begin{array}{l}\text { Stomach } \\
\text { Left lobe of Liver }\end{array}$ & Splenic tear & $\begin{array}{l}\text { Laparotomy } \\
\text { splenorrhaphy }\end{array}$ & 25 & $\begin{array}{l}\text { Discharged } \\
\text { Well }\end{array}$ \\
\hline 7 & 40 & Left & $\begin{array}{l}\text { Stomach } \\
\text { Transverse colon } \\
\text { Omentum }\end{array}$ & \# femur bilateral & $\begin{array}{l}\text { Laparotomy and } \\
\text { thoracotomy }\end{array}$ & 11 & $\begin{array}{l}\text { Discharged } \\
\text { Well }\end{array}$ \\
\hline 8 & 32 & Left & $\begin{array}{l}\text { Stomach } \\
\text { Omentum }\end{array}$ & $\begin{array}{l}\text { Splenic injury } \\
\text { \# right femur }\end{array}$ & $\begin{array}{l}\text { Laparotomy } \\
\text { Splenectomy } \\
\text { Plating for \# femur }\end{array}$ & 30 & $\begin{array}{l}\text { Discharged } \\
\text { Well }\end{array}$ \\
\hline 9 & 35 & Left & $\begin{array}{l}\text { Stomach } \\
\text { Omentum } \\
\text { Spleen }\end{array}$ & mesenteric injury & Laparotomy & 09 & $\begin{array}{l}\text { Discharged } \\
\text { Well }\end{array}$ \\
\hline 10 & 55 & Left & $\begin{array}{l}\text { Stomach } \\
\text { Omentum } \\
\text { Spleen }\end{array}$ & $\begin{array}{l}\text { Splenic injury } \\
\text { \# left humerus }\end{array}$ & $\begin{array}{l}\text { Laparotomy } \\
\text { Splenectomy }\end{array}$ & 39 & $\begin{array}{l}\text { Discharged } \\
\text { Well }\end{array}$ \\
\hline
\end{tabular}

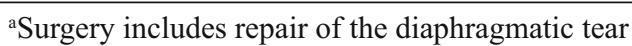

"Means fracture of the bone

Table 2 Delayed diaphragmatic herniation - patient data

\begin{tabular}{|c|c|c|c|c|c|c|c|}
\hline S. No & Age & Side of injury & Contents & $\begin{array}{l}\text { Interval between } \\
\text { Injury and } \\
\text { Presentation }\end{array}$ & Surgical Approach ${ }^{\mathrm{a}}$ & $\begin{array}{l}\text { Hospital Stay } \\
\text { (in days) }\end{array}$ & Outcome \\
\hline 1 & 35 & Left & $\begin{array}{l}\text { Stomach } \\
\text { Transverse Colon } \\
\text { Omentum }\end{array}$ & $\begin{array}{l}\text { RSA } 21 / 2 \text { months } \\
\text { prior }\end{array}$ & Abdominal & 09 & $\begin{array}{l}\text { Discharged } \\
\text { Well }\end{array}$ \\
\hline 2 & 29 & Left & $\begin{array}{l}\text { Stomach } \\
\text { Ileum }\end{array}$ & RSA $3 \frac{1}{2}$ years prior & Abdominal & 05 & $\begin{array}{l}\text { Discharged } \\
\text { Well }\end{array}$ \\
\hline 3 & 42 & Left & $\begin{array}{l}\text { Stomach } \\
\text { (volvulus) }\end{array}$ & $\begin{array}{l}\text { Fall from height } 11 \\
\text { months prior }\end{array}$ & Abdominal & 07 & $\begin{array}{l}\text { Discharged } \\
\text { Well }\end{array}$ \\
\hline 4 & 39 & Central & $\begin{array}{l}\text { Stomach } \\
\text { Transverse } \\
\text { Colon Omentum } \\
\text { Jejunum }\end{array}$ & $\begin{array}{l}\text { Stab injury } 20 \text { years } \\
\text { ago }\end{array}$ & Abdominothoracic & 33 & $\begin{array}{l}\text { Discharged } \\
\text { Well }\end{array}$ \\
\hline
\end{tabular}



RSA Roadside accident 


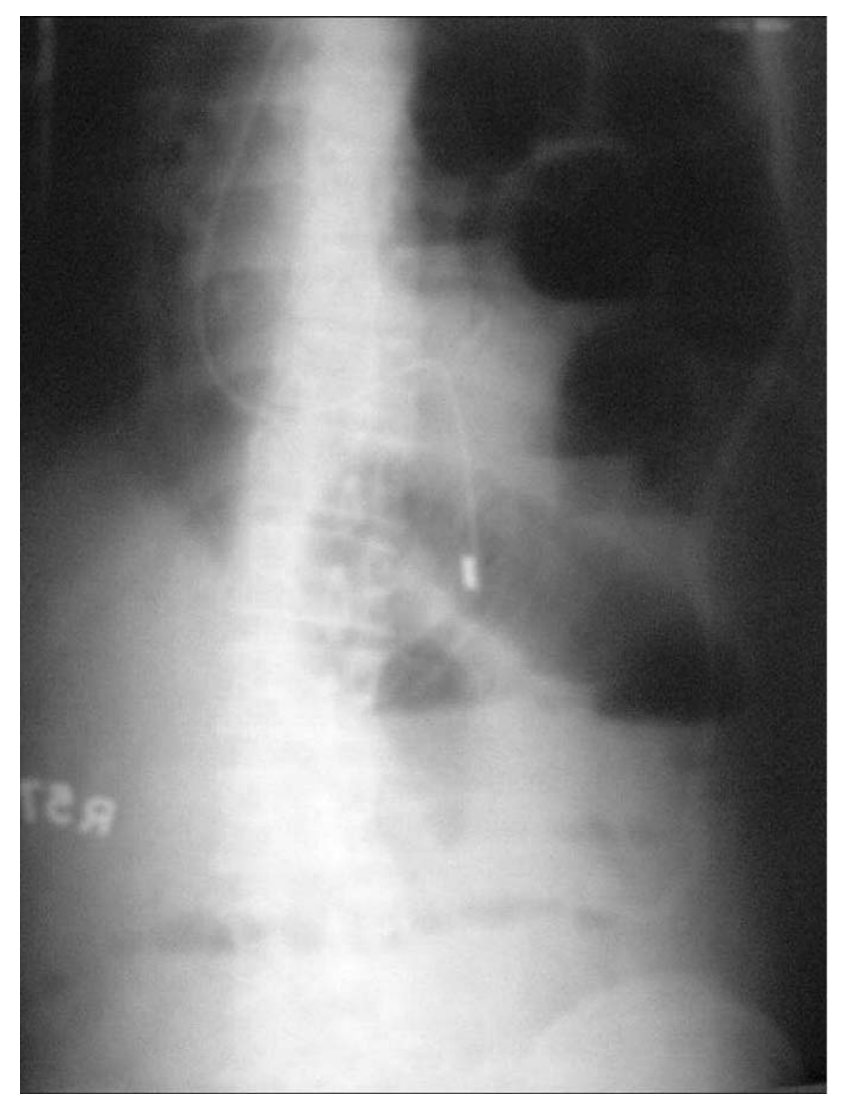

Fig. 6 TDH with colon loop visible in the left chest

potential defect or weakness of the diaphragm due failure of embryological development may further contribute in the development of TDH [5]. Once such a defect appears, progressive herniation of abdominal contents into the chest occurs either immediately, or later, due to a physiological intra-abdominal / intrathoracic pressure gradient that tends to push the abdominal contents upwards into the chest cavity [2].

TDH is more common on the left side (56 to $90 \%$ of cases), with herniation of the stomach and colon seen commonly. This side is considered to be a developmentally weaker area than the right [1]. In addition, the rarity of injuries on the right hemidiaphragm can also be explained by the facts that this side is protected by the liver, which can 'cushion' the impact, and also, the that the force required to produce a right sided TDH consequently has to be much greater, leading to a higher pre-hospital mortality - in other words, patients with right sided TDH usually do not survive because of the severe trauma sustained by them [2].

In an acute situation, the patients may present with symptoms of abdominal pain, shortness of breath and chest pain in addition to the symptoms of other injuries [1,2]. Although there are no pathognomic signs for TDH, decreased breath sounds on the affected side, coupled with the presence of bowel sounds in the chest on auscultation must alert the clinician to the possibility of having a diaphragmatic

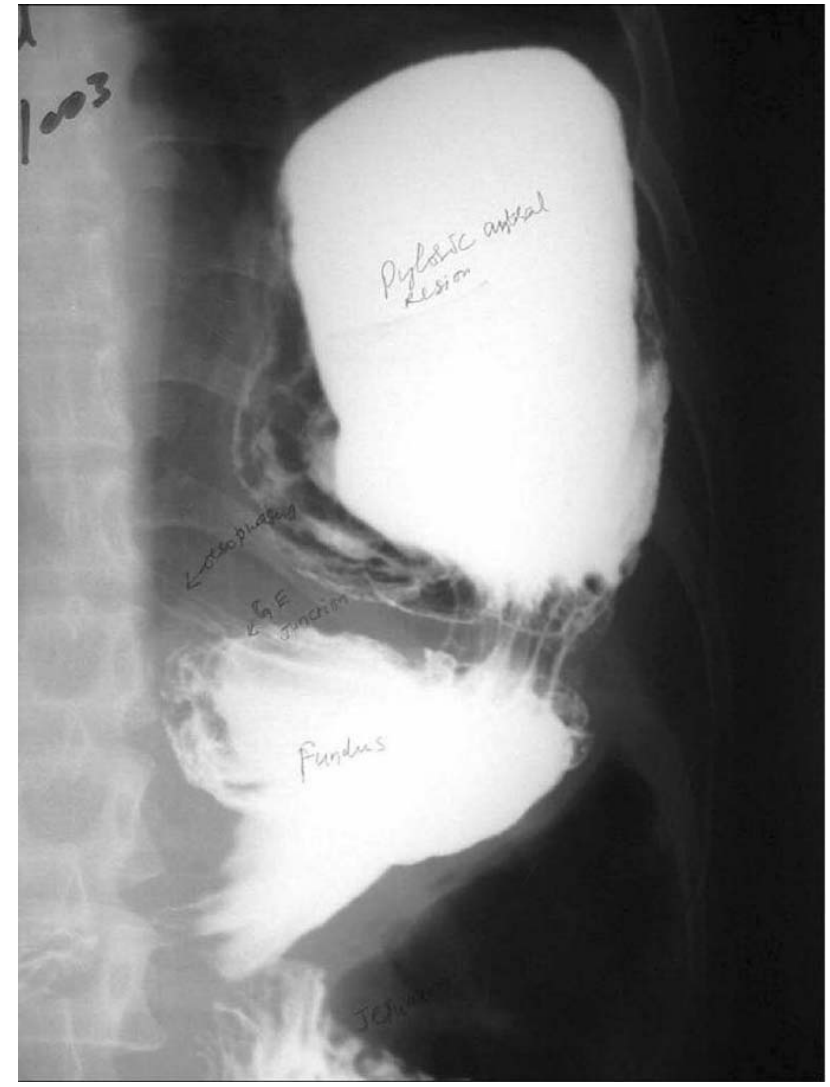

Fig. 7 Barium study in a case of delayed presentation showing volvulus of the stomach, with the pyloroantral region lying in the left chest

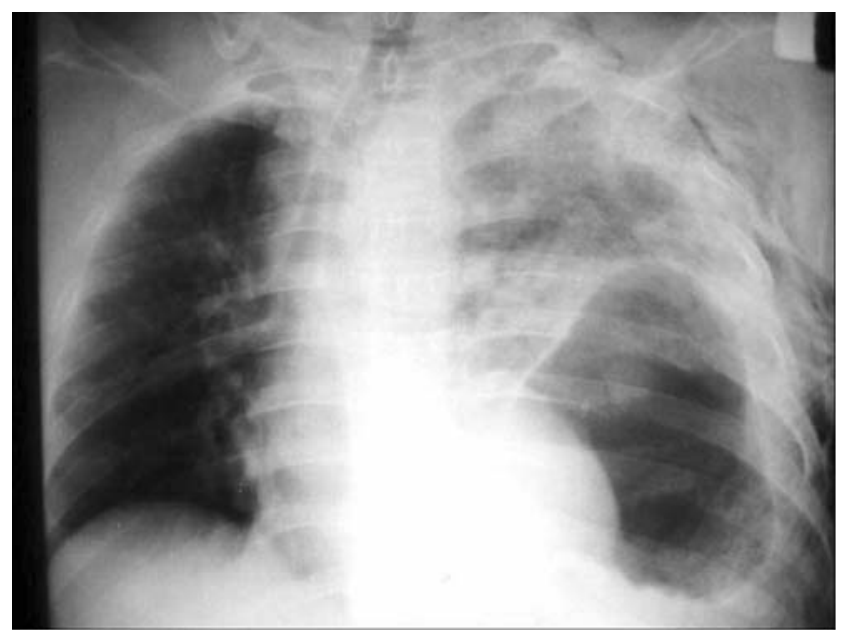

Fig. 8 Chest $x$ ray of a patient presenting late, with the gastric air bubble in the chest. Note the deviation of the trachea to the right side

injury and herniation. In the delayed presentation, the patient usually presents with the clinical features of respiratory difficulty (due to compression of the lung on the affected side) and intestinal obstruction (depending upon the hernial contents). 
The diagnosis of TDH may be established on a plain chest $\mathrm{x}$ ray or a computerized tomogram (CT) scan. Although an initial chest $x$ ray on admission may not establish the diagnosis, serial $\mathrm{x}$ rays may often reveal previously missed TDH. The diagnostic radiographic findings on $\mathrm{x}$ ray include gastric air bubble lying in the chest (Figs. 1-3, 8), visualization of the Ryle's tube in the chest (Fig. 4), herniation of bowel above the hemi diaphragm (Figs. 5 and 6) with a focal constriction at the site of tear (collar sign), loss or distortion of the outline of the hemidiaphragm, apparent elevation of the hemi diaphragm, pleural effusion and air fluid levels in lower thorax. Contralateral shift of the mediastinum and trachea may also be appreciated (Figs. 2, 3, 5 and 8). An erroneous diagnosis of tension pneumothorax may be made if the correct diagnosis is missed, with subsequent placement of a chest tube, the chance of injury to the herniated bowel, and fistula formation [6]. In delayed presentation, a dye study may make the diagnosis by clearly outlining the loop of intestine in the chest (Fig. 7). However, as we are all well aware, barium studies must be used with caution, or avoided altogether in cases where there is a high grade of obstruction or a suspicion of perforation. The diagnosis can also be established by a CT scan, which may have been performed to assess other intra-abdominal injuries in unsuspected cases. TDH may be directly visualized on CT as a discontinuity of the diaphragmatic crus, herniation of the stomach, bowel or other organs into the chest, or may be suggested by thickening of the hemidiaphragm with an adjacent hematoma $[1,2,7]$.

The treatment is surgical, as a spontaneous closure of the diaphragmatic defect is unlikely because of the continuing abdomino-thoracic pressure gradient that progressively pulls up the intraabdominal contents into the chest, and enlarges the defect [8]. The approach is by an abdominal route in cases that present early as this helps in tackling other associated intra-abdominal injuries also. In a delayed presentation, thoracotomy may be required, as the formation of adhesions with the intra-thoracic structures may not allow the contents to be reduced by a purely abdominal approach. Usually, a primary closure of the diaphragmatic defect using non-absorbable sutures is possible, but if the defect is large, a prosthetic (mesh) repair may be required $[1,4,5,7]$.

\section{References}

1. Mihos P, Potaris K, Gakidis J, Paraskevopoulos J, Varvatsoulis P, Gougoutas B, Papadakis G, Lapidakis E (2003) Traumatic rupture of the diaphragm: experience 65 patients. Injury Int J Care Injured 34:169-172

2. Killeen KL, Shanmuganathan K, Mirvis SE (2002) Imaging of traumatic diaphragmatic injuries. Semin Ultrasound, CT and MRI 23:184-192

3. Listopadzki D, Nowakowski M, Freeman S (2003) Traumatic diaphragmatic rupture presenting as delayed gastric outlet obstruction: case report. Gastrointest Endosc 58: 139-141

4. Sharma OP, Duffy B (2001) Transdiaphragmatic Intercostal Hernia: Review of World Literature and Presentation of a Case. J Trauma 50:1140-1143

5. Reina A, Vidana E, Soriano P, Orte A, Ferrer M, Herrera E, Lorenzo M, Torres J, Belda R (2001) Traumatic intrapericardial diaphragmatic hernia: case report and literature review. Injury Int J Care Injured 32:153-156

6. Rege SA, Narlawar RS, Deshpande AA, Dalvi AN (2001) Iatrogenic Gastric Fistula Due to Inappropriate Placement of Intercostal Draingae Tube in a Case of Traumatic Diaphragmatic Hernia. J Postgrad Med 47:108-110

7. Cupitt JM, Smith MB (2001) Missed Diaphragm Rupture Following Blunt Trauma. Anaesth Intensive Care 29:292-296

8. Simpson J, Lobo DN, Shah AB, Rowlands BJ (2000) Traumatic Diaphragm Rupture: Associated Injuries and Outcome. Ann R Coll Surg Engl 82:97-100 